\title{
Analysis of the Application-Type Undergraduate Education Accounting System Teaching System Construction
}

\author{
Zhao Li \\ Xizang Minzu University Xianyang, Shaanxi, 712082
}

Keywords: Application-oriented undergraduate education; accounting practice; teaching system construction; strategy analysis

\begin{abstract}
The application-oriented undergraduate education is targeted at bringing up application-type talents. With application as the development core, it attaches great importance to students' operational abilities and knowledge application abilities. The accounting practice teaching system constitutes an important part of the application-based undergraduate education, which can improve students' operational ability. This paper proceeds from the accounting practice teaching of the application-type undergraduate education. Based on basic conditions, requirements and development status of the practice teaching system construction, strategies for the system construction are expounded in detail.
\end{abstract}

Application-oriented undergraduate education is an educational activity with subject construction as its basis, satisfaction of learning demands as its basic direction, cultivation of professional abilities at its core, and improvement of vocational education quality as its goal. It can provide high-quality application-oriented undergraduate talents for all sections of society. Aiming at developing a large batch of high-quality and innovation-oriented talents, application-oriented undergraduate education plays an important role in improving students' application abilities of knowledge. Therefore, development of application-oriented undergraduate education has a close bearing on development of undergraduates' professional abilities. In application-oriented undergraduate education, accounting is a highly technical and practical subject. Its development process gives full expression to practicability, and its role in forging students' practical abilities, ability of innovation and ability of thinking cannot be ignored. This necessitates more attention paid to construction of the practice course system during the development process of the application-oriented undergraduate education.

\section{Status and existing problems of application-oriented undergraduate education accounting teaching system construction}

Application-oriented undergraduate education accounting practice teaching mainly follows the model of "course teaching + course practice teaching + graduation internship". Generally, practice teaching is carried out based on theoretical teaching. Table 1 presents a specific course system arrangement.

Application-oriented undergraduate education accounting practice teaching courses should be arranged strictly in accordance with the general curriculum requirements, based on accounting knowledge and professional skills of students, and including content which can contribute to students' practical skills. Meanwhile, the course content arrangement should attach importance to simulation. For example, handling of various vouchers, forms, data information and other materials required by operation and development of an enterprise should be simulated. Only when students are involved in such simulations can they continuously improve their basic accounting skills.

The application-oriented undergraduate accounting practice teaching environment generally includes the accounting simulation lab and the computer lab. Creation of a favorable environment can provide vigorous support for successful implementation of application-oriented undergraduate education accounting practice teaching.

In the current stage, application-oriented undergraduate education accounting practice teaching is 
still positioned as a teaching practice to bring up management elites. During its teaching system construction process, inadequate attention has been paid to practice teaching. As a result, students lack the ability to put their accounting knowledge into practice. This is not in line with requirement of the society and enterprises about talents.

Table 1. An arrangement of application-oriented undergraduate education accounting practice teaching

\begin{tabular}{|c|c|c|c|c|}
\hline Time & Freshman & Sophomore & Junior & Senior \\
\hline $\begin{array}{l}\text { Practical } \\
\text { Training }\end{array}$ & $\begin{array}{l}\text { Accounting } \\
\text { Principle } \\
\text { Manual } \\
\text { Simulation and } \\
\text { Field Survey }\end{array}$ & $\begin{array}{l}\text { (1) Financial } \\
\text { Accounting Manual } \\
\text { Simulation and Field } \\
\text { Survey } \\
\text { (2) Tax Declaration } \\
\text { and Field Survey }\end{array}$ & $\begin{array}{l}\text { (1) ERP Comprehensive } \\
\text { Field Survey } \\
\text { (2) Costing Field Survey } \\
\text { (3) Securities Investment } \\
\text { Field Survey } \\
\text { (4) Financial Management } \\
\text { Practice Field Survey }\end{array}$ & $\begin{array}{l}\text { (1) Audit Practice } \\
\text { Field Survey } \\
\text { (2) Financial } \\
\text { Statement Analysis } \\
\text { Field Survey } \\
\text { (3) Accounting } \\
\text { Comprehensive Field } \\
\text { Survey (Accounting } \\
\text { Computerization Field } \\
\text { Survey) }\end{array}$ \\
\hline
\end{tabular}

Accounting practice teaching usually confuse the concepts of practical abilities and operational abilities. Development of students' practical abilities, particularly the problem-solving ability, is ignored. This is not beneficial for long-term development of students' innovative thinking. Additionally, most accounting practice courses are revolved around financial accounting, but ignore other content related to accounting.

Smooth implementation of accounting practice teaching relies on support of relevant facilities, human resources and materials. However, accounting practice teaching is not equipped with necessary teaching facilities. This has seriously impaired the due teaching effects.

Accounting practice teaching is carried out both in and out of the campus. It can be concentrated or decentralized. The problem is that accounting practice teaching outside the campus is usually lacking enterprise support. The off-campus accounting practice course base construction is unstable.

\section{Application-oriented undergraduate education accounting teaching system construction conditions}

First, accounting lab. Application-oriented undergraduate education accounting practice teaching should have an independent lab. In the lab, the financial operation in a real enterprise can be simulated for students so that students can learn practical skills in an authentic environment. Second, high-quality faculty team. Effectiveness of application-oriented undergraduate education accounting practice teaching largely relies on a high-quality faculty team. Meanwhile, the faculty team should be continuously improved with periodical training taken. Third, accounting internship bae. Internship base construction can create more opportunities for students' accounting learning. More importantly, it can contribute to consolidation of students’ accounting knowledge.

Application-oriented undergraduate education accounting system teaching calls for corresponding institutional support. Under the institutional support, the teaching content, teaching scope, teaching methods, and way of assessment should be clarified. With an accounting teaching quality assurance system put in place, accounting teaching monitoring can be strengthened.

\section{Application-oriented undergraduate education practice teaching system construction improvement strategies}

The accounting practice teaching objective system should be formulated according to the talent development objectives and characteristics of accounting learning. To be specific, it should integrate objectives in different links of practice teaching. The accounting practice teaching objective system is at the core of accounting practice teaching activities. It can decide establishment 
of the practice teaching management system, guarantee system and content system.

Progressive and dynamic accounting teaching practice refers to the course-based accounting practice teaching implemented in accordance with the course teaching progress, teaching requirements and knowledge points. Take Accounting Principle for example. The practice courses of Accounting Principle should emphasize theoretical learning in the early stage, but shift its focus to improvement of practical skills in the later period. In other words, practice teaching should be carried out on the basis of theoretical teaching.

Traditionally, accounting practice courses are arranged according to the course schedule. They are usually given in two weeks after the end of the spring term and before the start of the summer vacation. During the accounting practice teaching period, teachers should actively seek off-campus internship opportunities for students to enrich their campus learning.

To be comprehensive, accounting practice courses should not be confined to campus practice teaching and off-campus internship. Instead, more innovation and entrepreneurship competitions should be held. Competitions like "Challenge Cup" and "Electronic Commerce Competition" will create opportunities for students about how to raise funds, prepare accounting statements, and analyze accounting indexes. Besides, the competition process is a process of honing students' logic thinking ability and language expression ability.

The accounting practice teaching textbooks should allow decomposition and integration. These textbooks should include not only major knowledge and skills delivered by specialized accounting courses, but also knowledge of financial statements, tax laws, and financial management. In this way, accounting practice teaching textbooks can have their teaching content further diversified and improved.

Currently, the accounting practice teaching just shows how to provide the original vouchers as to financial services. On the basis, accounting practice courses should pay more attention to improvement of students' ability to judge the enterprise's operation status based on the original vouchers. Students should be inspired to think and use their accounting knowledge to solve practical problems.

Construction of an accounting practice teaching management system can guarantee improvement of the accounting practice teaching quality. According to the content of the accounting teaching management system, duties of accounting practice teaching staff should be further clarified. The accounting practice teaching management institutions, standards and evaluation indexes should be further upgraded.

The accounting practice teaching guarantee system is made up of the faculty team, teaching facilities and teaching environment. Effective construction of the accounting practice teaching guarantee system can bolster improvement of accounting practice teaching effects. Therefore, it is necessary to further improve qualities of accounting practice teachers, create a simulated accounting practice teaching environment and tighten monitoring of the accounting practice teaching process.

First, accounting basic experimental platforms. These experimental platforms mainly serve accounting learning of sophomores and juniors. They can help students grasp accounting knowledge, improve operational skills and accounting abilities. Second, accounting professional and comprehensive experimental platforms. Experimental platforms of the kind are built after students finish all accounting learning. They train and improve students' practical skills based on their basic knowledge. Third, accounting specialized and comprehensive experimental labs. Experimental labs of the kind can contribute to students' cooperativeness and practical abilities. They are usually set up in the second semester of the senior year. The basic experimental form is the ERP sand-table simulated competition.

In the fourth year of students' accounting year, institutions of higher learning usually provide students with three opportunities of accounting internship. The first internship is arranged before students start a comprehensive learning of specialized courses. The internship is to enhance students' perception of the major. The second internship is arranged after students finish the comprehensive specialized course learning. In this period, the internship is arranged by teachers, and students are sent to enterprises for internship. The internship can deepen students' 
understanding of principles of corporate production and operation activities. The third internship is arranged before students' graduation. The internship is mainly for the purpose of genuinely integrating students into the corporate accounting management work. Usually, students are involved in such internship under the guidance of supervisors.

Accounting practice teaching platforms mainly include social surveys, social practices, course design, and graduation paper design. Social surveys are usually arranged in the junior or senior year. Based on the requirements of graduation paper design, the supervisor and the student jointly identity the topic of social survey. The social practices are also carried out among juniors and seniors. In general, students are sent to specific areas or specific enterprises, either jointly or separately, for internship. Course design is also for juniors and seniors, whose purpose is to support students’ graduation design.

\section{Conclusion}

To sum up, application-oriented undergraduate accounting practice teaching system construction can enhance students' accounting theoretical and practice learning, improve their abilities to use accounting knowledge to solve practical problems, and continuously upgrade their comprehensive accounting qualities. Considering all these benefits, it is necessary to accelerate construction of an application-oriented undergraduate accounting practice teaching system on the basis of fully respecting talent development goals. Only in this way can high-quality talents be continuously brought out to serve social development.

\section{References}

[1] Ao D. S. Construction and implementation of the applied undergraduate accounting practice teaching system[J]. Commercial Accounting, 2010, (02): 68-69.

[2] Xu. Zh. C. \& Zh. L. X. On teaching of practice for application-typed undergraduate colleges[J]. Journal of Chuzhou University, 2010, 12 (030: 80-84.

[3] Zhu. J. Construction and practice in practical teaching system of applied undergraduate welding major[J]. China Metallurgical Education, 2010, (05): 57-59+62.

[4] Shi Y. Q., Guan A. Zh., Zhu B. W., et al. Modularized curriculum system reformation for application-oriented undergraduate cultivation[J]. Journal of Zhejiang University of Science and Technology, 2010, 22 (05): 456-460.

[5] Guo M. X. Construction of the applied undergraduate education accounting practice teaching system[J]. Finance and Accounting Monthly, 2010, (36): 98-100.

[6] Zhang J. E. A tentative analysis of the specialized practice teaching system for the application-oriented higher education management majors-Taking Logistics Management as a case study[J]. Heilongjiang Researchers on Higher Education, 2013, 31 (02): 166-169.

[7] Zhang J. Construction of the specialized practice teaching system for the application-oriented undergraduate educational labor and social security majors[J]. Estate and Science Tribune, 2013, 12 (01): 148-150.

Topic: This paper is the research project of teaching reform and research of Tibet University for nationalities, which was presided by Zhao $\mathrm{Li}$ in 2016. It is based on the training of professional judgment ability of comprehensive accounting talents. Item number: 2016323

\section{Introduction of the Author:}

Zhao Li (1976.11--) Xianyang Shaanxi Province, School of Finance and Economics in Xizang Minzu University, Associate professor , Orientation for study: theory and practice of accounting 